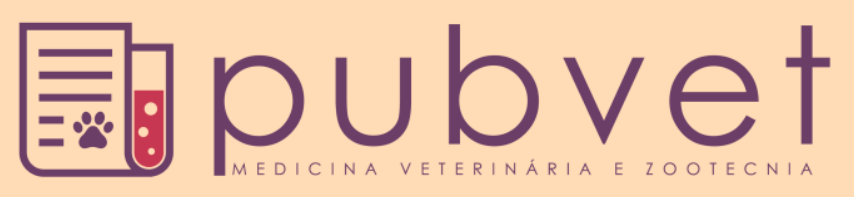

https://doi.org/10.22256/pubvet.v12n3a47.1-8

\title{
Ossifying fibroma in a dog
}

\author{
Roberto Carlos Mourão Pinho ${ }^{\ominus 1,2^{*}}$, André Cavalcante da Silva Barbosa ${ }^{\bullet} 1$, Arnaldo de \\ França Caldas Júnior ${ }^{\ominus}$, Renata Cimões ${ }^{\ominus}$, Fernando Leandro dos Santos ${ }^{\ominus}$
}

${ }^{I}$ Federal University of Pernambuco;

${ }^{2}$ Military Police of Pernambuco.

${ }^{3}$ Rural Federal University of Pernambuco.

*Corresponding author,E-mail: robertomouraopinho@yahoo.com.br

\begin{abstract}
Epulis refers to any tumor or similar growth on the gingival tissue and is considered the most frequent of benign oral masses in dogs. Epulis is classified into four types based on histological characteristics: fibromatous, ossifying, acanthomatous and giant cell. The aim of the present study was to present knowledge on benign oral tumors and epulides as well as report a clinical case of ossifying epulis in a male dog (Labrador) aged 25 months. The integrated treatment plan initiated with a diagnostic investigations through hematological, biochemical and serological exams for the study of antibodies for ehrlichiosis, anaplasmosis, dirofilariasis and Lyme disease as well as electrocardiogram and intraoral and thoracic x-rays, followed by the removal of the suspected tumor mass through excisional biopsy. The sample was sent for histopathological analysis for the definitive diagnosis, which confirmed ossifying epulis. In conclusion, surgery was the treatment of choice and only a histopathological analysis can confirm the type of oral neoplasm and prognosis.
\end{abstract}

Keywords: oncology, gingival tissue, dog, fibroma, ossifying

\section{Ossificação de fibroma em cão}

RESUMO. Epulis refere-se a qualquer tumor ou crescimento semelhante no tecido gengival e é considerado o mais frequente de massas bucais benignas em cães. Epulis é classificado em quatro tipos com base em características histológicas: células fibromáticas, ossificantes, acantomatosas e gigantes. O objetivo do presente estudo foi apresentar conhecimento sobre tumores e epúlides bucais benignos, além de relatar um caso clínico de epúlsis osificante em um cão macho (Labrador) com 25 meses de idade. O plano de tratamento integrado iniciou-se com uma investigação diagnóstica através de exames hematológicos, bioquímicos e serológicos para o estudo de anticorpos para ehrlichiosis, anaplasmose, dirofilíase e doença de Lyme, bem como eletrocardiograma e radiografias intraorais e torácicas, seguido da remoção do tumor suspeito Massa através de biópsia excisional. A amostra foi enviada para análise histopatológica para o diagnóstico definitivo, que confirmou epulis ossificante. Em conclusão, a cirurgia foi o tratamento de escolha e apenas uma análise histopatológica pode confirmar o tipo de neoplasia oral e prognóstico.

Palavras chave: oncologia, tecido gengival, cão, fibroma, ossificação

\section{Osificación de fibroma en un perro}

RESUMEN. Epulis se refiere a cualquier tumor o crecimiento similar en el tejido gingival y se considera una de las masas bucales benignas más frecuente en perros. Épulis se clasifica en cuatro tipos basados en características histológicas: células fibromáticas, 
osificantes, acantomatosas y gigantes. El objetivo del presente estudio fue presentar conocimiento sobre tumores y épulis bucales benignos, además de relatar un caso clínico de épulis osificante en un perro macho (Labrador) con 25 meses de edad. El plan de tratamiento integrado se inició con una investigación diagnóstica a través de exámenes hematológicos, bioquímicos y serológicos para el estudio de anticuerpos para ehrlichiosis, anaplasmosis, dirofiliasis y enfermedad de Lyme, así como electrocardiograma y radiografías intraorales y torácicas, seguido de la remoción del tumor sospechoso Masa a través de la biopsia excisional. La muestra fue enviada para análisis histopatológicos para el diagnóstico definitivo, que confirmó épulis osificante. En conclusión, la cirugía fue el tratamiento de elección y sólo un análisis histopatológico puede confirmar el tipo de neoplasia oral y pronóstico.

Palabras clave: oncología, tejido gingival, perro, fibroma, osificación

\section{Introduction}

The oral cavity is a complex structure formed by different types of tissues, each of which can give rise to a variety of growth classified as either benign or malignant depending on the biochemical, morphological and functional characteristics (De Nardi et al., 2002) as well as the origin of the embryonic tissues (Verstraete, 2005). Malignant tumors cause greater destruction to the tissue and often lead to the death of an animal, whereas benign tumors cause direct tissue morbidity, but do not result in a high mortality rate (Liptak \& Withrow, 2007).

Neoplasms are common in canines and oral tumors account for $6 \%$ of all neoplasms in this species ${ }^{4}$, making the oral cavity the fourth most frequent site for such tumors (White, 2003). The most common benign tumors in dogs are fibromatous epulis, acanthomatous epulis, ameloblastoma and papilloma (White, 2003). Epulides are classified in four groups based on histological characteristics: fibromatous, ossifying, acanthomatous and giant cell (Wiggs \& Lobprise, 1997).

Among oral masses in dogs, epulis is the most commonly encountered benign tumor in veterinary dentistry. This is a growth that presents as firm, solid, with a peduncled appearance growing around the gingival tissue (Oakes et al., 1993), originating from the stroma of the periodontal ligament (White, 2003) and histologically classified as acanthomatous, ossifying or fibromatous, the latter of which is the most frequent form and generally not very invasive. The ossifying form resembles the fibromatous form and radiographically presents as calcified or, in some cases, causes osteolysis. Acanthomatous epulis is the most invasive form of the three and often demonstrates areas of osteolysis during a radiographic examination, but does not metastasize. Due to this aggressive characteristic, bone resection is sometimes necessary to achieve satisfactory treatment results (Oakes et al., 1993).

This type of exophytic growth in the gingival tissue must be classified histologically (Verstraete et al., 1992), as the macroscopic clinical appearance can cause confusion regarding the origin and classification of the tumor, making it difficult to determine the nature of the tumor, prognosis and potential for metastasis. Thus, a biopsy and histological analysis are necessary to enable the classification of epulides as fibromatous, ossifying, acanthomatous (Barker et al., 1993, Dubielzig et al., 1979, Meuten, 2016); or giant cell (Valentine \& Eckhaus, 1986, Yoshida et al., 1999).

An ossifying epulis, which is also denominated peripheral odontogenic fibroma (Holmstrom, 1995), is a calcifying epithelial odontogenic tumor with slow growth made up of firm masses that are normally covered with intact epithelium. This form of epulis exhibits the same biological behavior as the fibromatous form and its main microscopic characteristic is the presence of subgingival stroma and an extensive bone matrix (Harvey \& Emily, 1993). Histologically, an osteoid formation in dogs is found in the stromal component of the submucosa, with the osteoid formed by astrocytes and dense fibrillar collagen, with the presence of material similar to dentin or cementum or an osteoid in fibrous tissue. Islands of epithelium are usually found adjacent to the ossified tissue (Yoshida et al., 1999), which is more resistant to resection due to its greater consistency (Dhaliwal et al., 1998).

According to Roza (2004), an ossifying epulis does not require radical resection due to the low incidence of recurrence. However, Birchard \& Sherding (2008) state that this form of epulis can 
transform into an osteosarcoma. Thus, recurrence is possible up to four months after the initial surgery and block resection with a margin of safety is the best indication (Woodward, 2002).

The most commonly found clinical signs are halitosis, weight loss, increased salivation, dysphagia (Rodrígues-Quirós et al., 1998, White, 2003, Withrow et al., 2014), nasal discharge, oral bleeding, pain upon exploration of the oral cavity, tooth mobility (Oakes et al., 1993, Marreta, 1998, Stebbins et al., 1989, Tholen \& Hyot, 1989), malocclusion and protrusion of the oral cavity (Nelson \& Couto, 2015). Other clinical signs include an increase in oral volume with a consequent altered facial contour, pain upon opening the mouth, passing the paws over the mouth, cough, shortness of breath, chronic rhinitis, anorexia, weight loss, jaw fracture due to severe bone impairment (Wiggs \& Lobprise, 1997, Morris \& Dobson, 2001), lack of appetite, dysphagia and food dropping from the mouth (Polton, 2011).

Gingival tumors can invade other periodontal structures, causing mobility, displacement of the adjacent tooth and even tooth loss. Growths that disseminate to the maxilla can extend to the nasal cavity and perioribitary tissue, producing an asymmetrical increase in facial volume and even exophthalmia (Wiggs \& Lobprise, 1997).

During diagnosis, data on the species, breed, sex and age should be considered, as the probability of the occurrence of neoplasms may be associated with one of these characteristics (Verstraete et al., 1992). During the physical examination, the oral cavity must be investigated, the suspected mass must be evaluated and an exploration of regional lymph nodes should be performed (Verstraete, 2005). The ventral surface of the oral cavity, tongue, gingival tissues, dental arches, tonsils, palate, and lips should also be inspected (Birchard \& Sherding, 2008, Nelson \& Couto, 2015).

Oral neoplasms often go unperceived by the animal's owner until the tumor reaches an advanced state (Leib \& Monroe, 1997). Thus, a precise diagnosis is fundamental, as some benign oral tumors could be confused with malignant processes (San Román, 1999). More aggressive oral masses can place the life of the animal at risk (Hitt et al., 2003), which makes an early diagnosis fundamental to the institution of effective treatment, resulting in a better prognosis (Pavlica et al. 2001).
The definitive diagnosis is based on the result of the histopathological analysis (Marreta, 1998). The nature, location and extent of the tumor determines the biopsy technique to be employed (Marreta, 1998, Birchard \& Sherding, 2008). An incisional biopsy is indicated for large masses for which surgical excision is difficult (Soderstrom \& Gilson, 1995, Withrow et al., 2014). Excisional biopsy with the entire removal of the mass and margins of safety is used for small masses, such as papillomas, epulides and labial melanomas (Soderstrom \& Gilson, 1995, Verstraete, 2005). In most cases, the risks related to a biopsy are minimal, with local bleeding the most common complication (Liptak \& Withrow, 2007).

Complementary laboratory exams for the evaluation of the organic health of the animal are also recommended (Oakes et al., 1993). The aim of such exams is to determine the systemic consequences of these oral tumors and discard a possible concurrent disease or paraneoplastic syndrome (hypercalcemia, hypoglycemia, leukocytosis, erythrocytosis, thrombocytopenia, disseminated intravascular coagulation and hyperproteinemia), which can determine the need for general anesthesia (Holmstrom, 1995).

Radiographic exams of the head are useful to the evaluation of bone anomalies (Verstraete, 2005). Intraoral $\mathrm{x}$-rays can also provide information regarding the size, shape, margination, opacity, position and displacement of structures (Rosenthal, 2004). Bone involvement can be evidenced radiographically based on degrees of bone resorption or proliferation (Wiggs \& Lobprise, 1997, Verstraete, 2005). It is always recommended to obtain thoracic $\mathrm{x}$-rays under anesthesia for the control of the occurrence of metastases in the lungs (Polton, 2011), 2011).

The preservation of soft issues is of inestimable value to ensure acceptable functional and esthetic results (López Arranz, 1991). The aim of oral neoplastic therapy should be the elimination of the affected tissue while preserving function and, if possible, the esthetic appearance of the oral cavity (Birchard \& Sherding, 2008). There are diverse therapeutic modalities for dogs and cats, such as surgical excision, systemic or intra-tumor chemotherapy, radiotherapy, cryotherapy and immunotherapy (Mayer \& Anthony, 2007) used either alone or in combination (Morris \& Dobson, 2001), among which surgery is the most employed and achieves the best results (Wiggs \& Lobprise, 1997). For a favorable prognosis (less likelihood 
of recurrence), surgical resection with a broad margin of safety is necessary(Liptak \& Withrow, 2007).

\section{Case description}

A male Labrador retriever aged 25 months and weighing $31 \mathrm{Kg}$ belonging to the military police of the state of Pernambuco, Brazil, was seen at the canine clinic of the $1^{\text {st }}$ Canine Policing Company presenting with a protrusion of the lower lip, with exteriorization and the visualization of a large hyperplastic mass in the oral cavity (Figure 1). The clinical examination of the oral cavity revealed that the vestibular region of the mandibular incisors exhibited a large hyperplastic formation of pinkish coloration and a firm consistency with a smooth surface and no ulceration that partially covered the central and lateral incisors and displaced the lower lip in the rostral direction, leading to labial protrusion. The animal was well fed and no tartar buildup was found. The dog had a good general health state. The heart rate was 80 beats per minute, respiratory rate was 32 breaths per minute and temperature was $38.4^{\circ} \mathrm{C}$. Epulis was the presumed diagnosis and surgical resection was indicated as treatment. A radiographic exam was performed under anesthesia just prior to surgery.

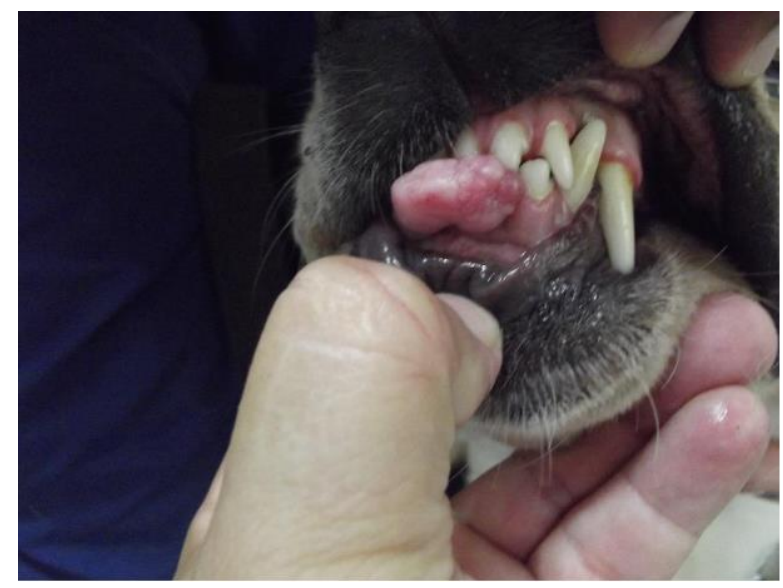

Figure 1. Detail of neoplastic growth covering mandibular central and lateral incisors in male Labrador retriever

Complementary preoperative exams were performed. Blood was collected for the complete blood count, platelet count and serology (ELISA Snap 4dx, Idexx laboratories) for the study of anaplasma, ehrlichiosis, Lyme disease and dirofilariasis. Biochemical exams were performed for the determination of levels of TGO, TGP, blood sugar, urea, creatinine, alkaline phosphatase, total proteins and protein fractions. All blood results were within the range of normality and the ELISA serological results were negative. The heart evaluation involved an electrocardiogram, using a digital 12-channel electrocardiograph (Tecnologia Eletrônica Brasileira, São Paulo, Brazil), the results of which were within the range of normality.

After fasting for 12 hours, the animal was submitted to pre-anesthetic medication, which consisted of the intramuscular administration of midazolam (Eurofarma) at a dose of $0.5 \mathrm{mg} / \mathrm{Kg}$ and an intravenous administration of propofol (AstraZeneca) at a dose of $4 \mathrm{mg} / \mathrm{kg}$. Tracheal intubation was then performed and the animal was positioned for the intraoral x-ray using IO-41 occlusal film measuring 57 x $76 \mathrm{~mm}$ (Kodak). Dental x-ray equipment (Gnatus) was used, operating at $70 \mathrm{Kva}$, with immediate development and fixation using a developer (Kodak) and fixer (Kodak), for intraoral x-ray of mandibular incisors of male Labrador, radiopaque area suggestive of calcification in neoplasm (Figure 2). The animal was anesthetized with intravenous acepromazine (Acepran $0.2 \%$, Vetnil) $0.05 \mathrm{mg} / \mathrm{kg}$, diazepam (Germed) $0.2 \mathrm{mg} / \mathrm{kg}$ and ketamine (Dopalen, Ceva) $6 \mathrm{mg} / \mathrm{kg}$, using the method described by Natalini (2007).

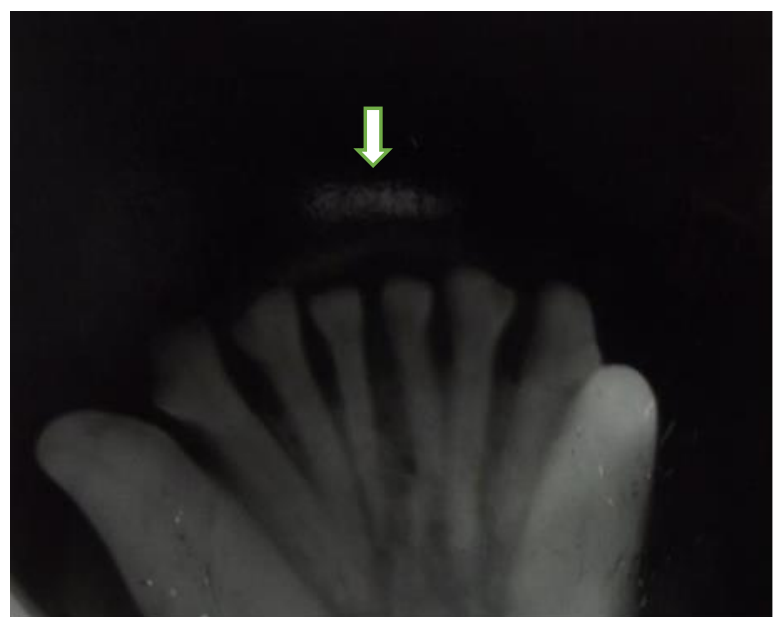

Figure 2. Intraoral $x$-ray of mandibular incisors of male Labrador; arrow: radiopaque area suggestive of calcification in neoplasm.

The animal was duly positioned in right lateral decubitus, followed by oral antisepsis with chlorhexidine $0.12 \%$ (Periogard Colgate) and local anesthesia in the region of the left and right mental foramens using Mepivacaine (Mepivacaine, Mepiadre DFL) with vasoconstrictor.

Excision of the neoplastic mass from the gingival tissue was performed with a margin of safety in terms of height and thickness using a $n^{\circ}$ 
15 scalpel and electric scalpel with a knife-type electrode. The excised tissue was slightly resistant to cutting, resembling ossified tissue. Final curettage was performed of the area with a periapical curette. A bone file was used for smoothing the cut tissue or bone spicules. Hemostasis was performed with an electric scalpel with a ball-type electrode (Figure 3).

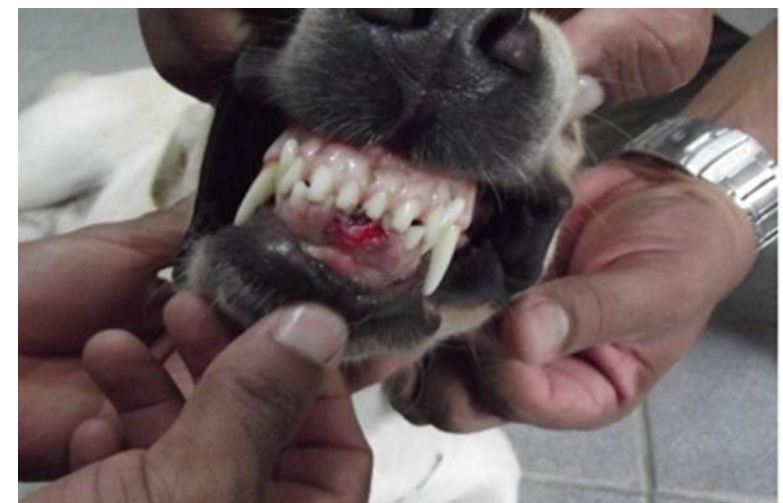

Figure 3. Appearance of oral cavity of male Labrador immediately after surgery

During surgery, tramadol (Pfizer) was administered intramuscularly at a dose of $2 \mathrm{mg} / \mathrm{kg}$ via intramuscular. At the end of anesthetic recovery, meloxicam (Maxican, Ouro Fino) was administered orally at a dose of $0.2 \mathrm{mg} / \mathrm{kg}$ at 24 hour intervals, dipirona (500 mg, Medley) was administered orally at a dose of $15 \mathrm{mg} / \mathrm{kg}$ at 12 hour intervals and marbofloxacin (Marbopet, CEVA) was administered orally at 24-hour intervals for ten days. Surgical cement (Coe-Pak GC, America Inc.) was placed at the excision site and remained as curative protection for the first 24 hours, when local hygiene was performed with the gentle administration of chlorhexidine $0.12 \%$ (Periogard Colgate) twice per day for five days. No special diet was recommended and the animal continued to receive dry chow twice per day.

The excised hyperplastic mass was dried at the base with gauze and immediately placed in a $10 \%$ formalin solution for fixation. The specimen was sent to the histopathology laboratory in the animal pathology sector of the veterinary hospital of the Rural Federal University of Pernambuco for processing. The tissues were embedded in paraffin, cut to a thickness of $5 \mu \mathrm{m}$ and stained with hematoxylin and eosin (HE), following the method described by Lucena et al. (1996) and Velásquez et al. (2005). The slides were analyzed and classified based on Yoshida et al. (1999), and re-evaluated by two pathologists for the confirmation of the diagnosis. The definitive histopathological diagnosis was ossifying epulis (Figure 4).

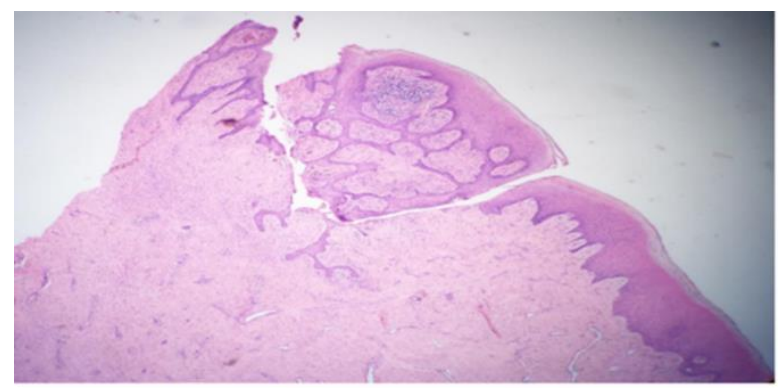

Figure 4. Gingival sample; a) thick keratinized epithelial tissue with acanthosis and sequestration of fibrous connective tissue; b) Granulomatous inflammatory process; c) abundant fibrous connective stroma (magnification: $35 \mathrm{X}$; $\mathrm{HE}$ staining).

The surgical wound was monitored daily for the follow up of the healing process. No change in medication was prescribed. Chest $\mathrm{x}$-rays were performed to monitor the occurrence of pulmonary metastases (Figures 5 and 6 ).

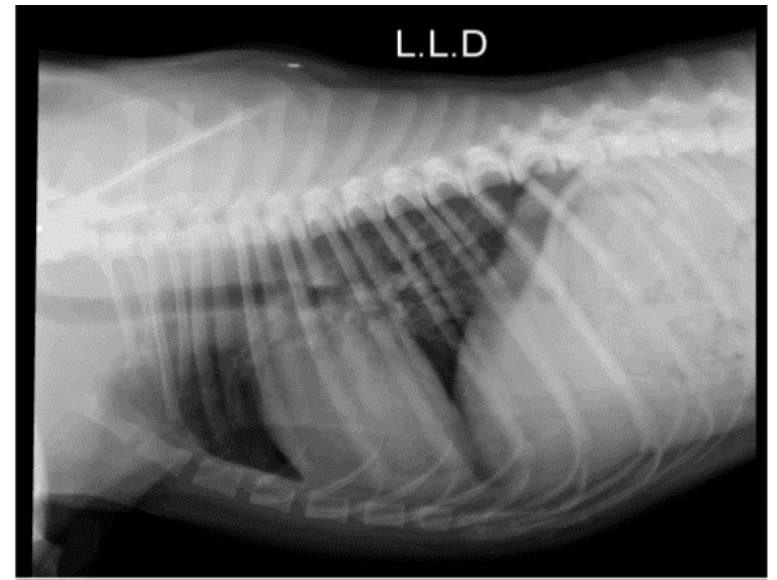

Figure 5. X-ray of thorax of male Labrador in right lateral decubitus 120 days after removal of oral neoplastic mass

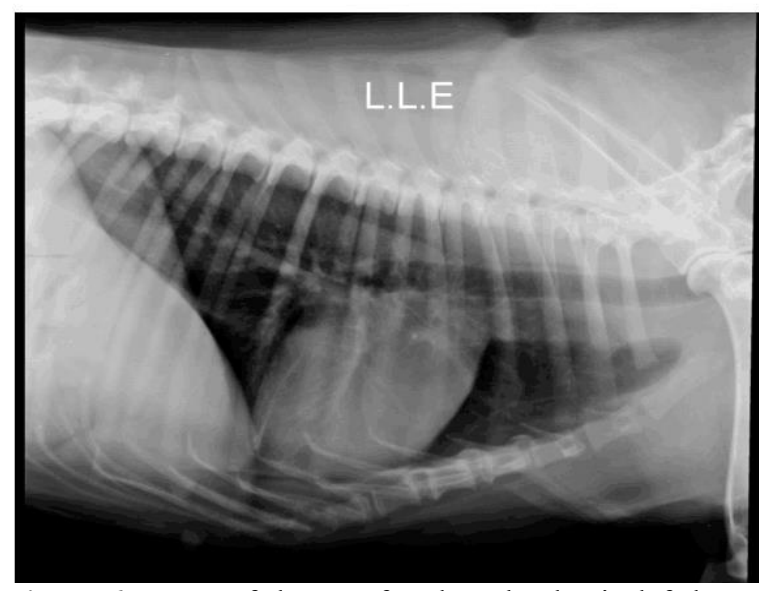

Figure 6. X-ray of thorax of male Labrador in left lateral decubitus 120 days after removal of oral neoplastic mass 


\section{Discussion}

The oral cavity of dogs is formed by different types of tissue that can give rise to a variety of malignant or benign neoplasms, which account for $6 \%$ of all neoplasms in this species (Gomes et al., 2009). Such tumors generally occur in older dogs and are rare in young dogs (Ferro et al., 2004). In the case reported herein, an oral neoplasm was found in a male Labrador retriever aged 25 months, with a presumed diagnosis of a benign oral neoplasm, which was considered unusual, given the age of the animal. The definitive diagnosis of ossifying epulis was given by the histopathological analysis.

Due to the lack of verifying the oral cavity of dogs, many oral tumors often go overlooked (Verstraete, 2005) and are generally only noted by the owner when already affecting a large area, which implies a more advanced stage and greater risk of malignancy, as benign tumors can become malignant over time (Sorenmo et al., 2009). In the present case, a large neoplastic mass was found in the vestibular region involving the mandibular incisors. The growth was not affecting the occlusion and consequently did not pose any difficulties with regard to feeding, but the large volume projected the lip in the rostral direction, deforming the region.

The precise diagnosis of a neoplasm is fundamental to the success of treatment. Moreover, laboratory exams, radiology (Figure 2), electrocardiography are important to the successful execution of the surgical planning, as surgery is the most effective treatment method. The macroscopic appearance of the tumor does not enable a definitive diagnosis or prognosis. Therefore, surgery and the histopathological analysis of the sample are always necessary (Marreta, 1998).

In the present case, postoperative therapy was used to control pain. Moreover, the antibiotic employed was marbofloxacin rather than ampicillin, clindamycin or metronidazole recommended by San Román (1999). Indeed, marbofloxacin proved to be adequate in this case.

During excision, the tumor mass demonstrated a resilient aspect and was difficult to remove. The histopathological analysis (Figure 4) revealed the presence of mature bone trabeculae (Figures 8 and 9), confirming the clinical diagnosis of ossifying epulis. Moreover, the epithelial clump confirmed the odontogenic nature of the growth (Figure 7).

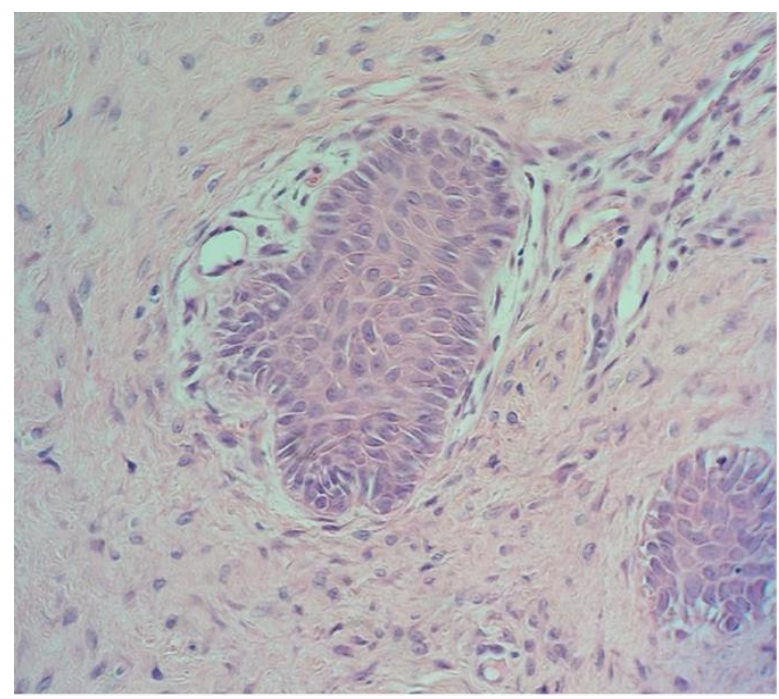

Figure 7. Specimen of gingival tissue with epulis revealing remaining epithelial clump of dental lamina (magnification: $400 \mathrm{x}$; HE staining)

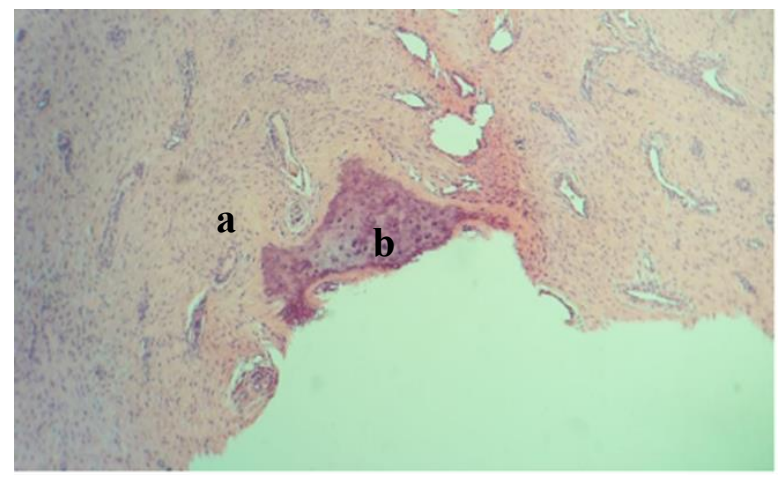

Figure 8. Specimen of gingival tissue with epulis; a) fibrous connective tissue, abundant collagen; b) mature bone trabecula (magnification: $60 \mathrm{x}$; HE staining)

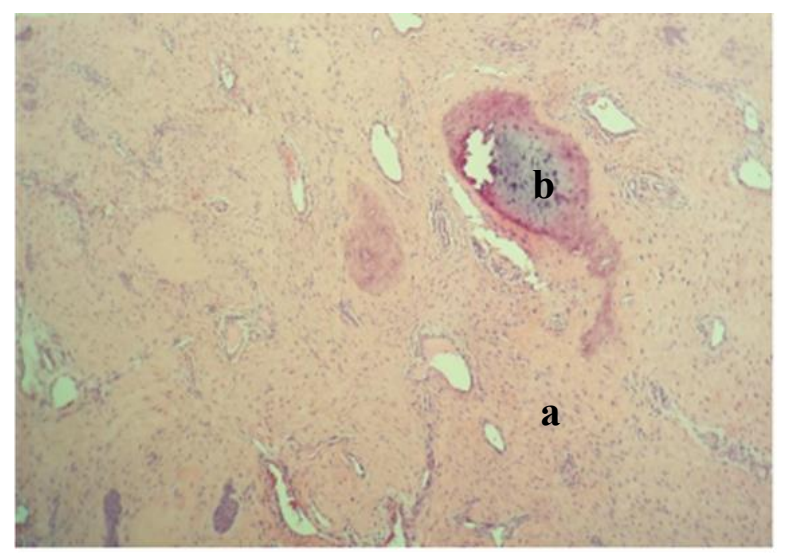

Figure 9. Specimen of gingival tissue with epulis; a) fibrous connective tissue, abundant collagen; b) mature bone trabecula (magnification: $60 \mathrm{x}$; HE staining)

Postoperative follow up consisted of daily monitoring of the healing process (Figure 10). Radiographic control of the thorax (Figures 5 and 6) demonstrated a pattern of normality, with the absence of pulmonary metastases. 


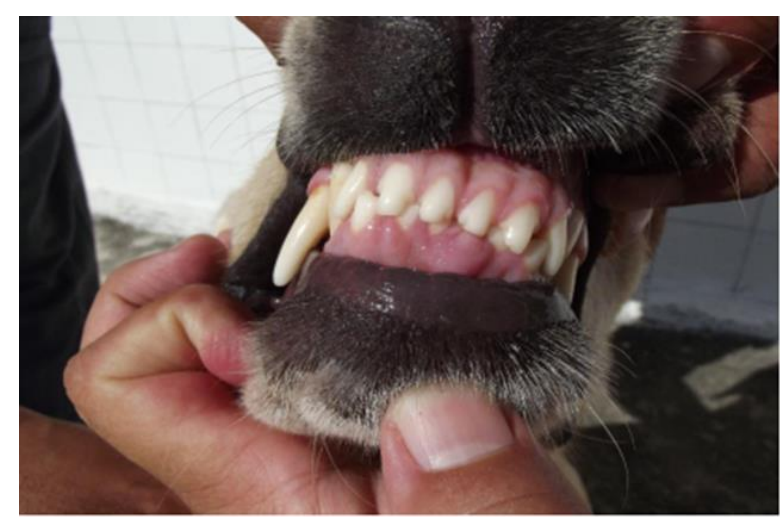

Figure 10. Appearance of male Labrador in right lateral decubitus 126 days after removal of oral neoplastic mass

\section{Conclusions}

The present case report demonstrates that benign oral neoplasms in the oral cavity of dogs can often go unperceived by the owner. Moreover, the clinical appearance does not enable a veterinarian establish a definitive diagnosis and prognosis without a histological analysis. The present case also underscores the need for early detection of such a growth as well as diagnostic exams, such as hematological, biochemical and radiographic (oral cavity and thorax) exams, to ensure the best treatment and wellbeing of the patient, reduce the risk of surgical complications and diminish the possibility of malignant transformation.

In conclusion, surgery with biopsy is the treatment of choice in cases of ossifying epulis and the use of mediations to control pain, antibiotics and oral antisepsis is necessary to the success of the procedure. Moreover, only a histopathological analysis can establish the reliable diagnosis and prognosis, enabling the adequate conduct of clinical and surgical cases involving oral neoplasms.

\section{References}

Barker, I., Van Dreumel, A. A. \& Palmer, N. 1993. The Alimentary System. Pathology of domestic animals, 2, 141-144.

Birchard, S. J. \& Sherding, R. G. 2008. Manual Saunders: clínica de pequenos animais, São Paulo.

De Nardi, A. B., Rodaski, S., Sousa, R. S., Costa, T. A., Macedo, T. R., Rodigheri, S. M., Rios, A. \& Piekarz, C. H. 2002. Prevalência de neoplasias e modalidades de tratamentos em cães, atendidos no hospital veterinário da Universidade Federal do Paraná. Archives of Veterinary Science, 7, 15-26.

Dhaliwal, R. S., Kitchell, B. E. \& Marretta, S. M.
1998. Oral tumors in dogs and cats. II. Prognosis and treatment. Compendium on Continuing Education for the Practicing Veterinarian, 20, 1109-1119.

Dubielzig, R. R., Goldschmidt, M. H. \& Brodey, R. S. 1979. The nomenclature of periodontal epulides in dogs. Veterinary Pathology, 16, 209-214.

Ferro, D. G., Lopes, F. M., Venturini, M. A. F. A., Correa, H. L. \& Gioso, M. A. 2004. Prevalência de neoplasias da cavidade oral de cães atendidos no Centro Odontológico Veterinário-Odontovet ${ }^{\circledR}-\mathrm{SP}$-entre 1994 e 2003. Arquivos de Ciências Veterinárias e Zoologia da UNIPAR, 7, 129-133.

Gomes, C., Oliveira, L. O., Elizeire, M. B., Oliveira, M. B., Oliveira, R. T. \& Contesini, E. A. 2009. Avaliação epidemiológica de cães com neoplasias orais atendidos no Hospital de Clínicas Veterinárias da Universidade Federal do Rio Grande do Sul. Ciência Animal Brasileira, 10, 835-839.

Harvey, C. E. \& Emily, P. 1993. Small animal dentistry, St. Louis: Mosby.

Hitt, M. E., Zoran, D. L. \& De Bowes, L. J. 2003. Diseases of the oral cavity and pharynx. In: Morgan, R. V., Bright, R. M. \& Swartout, M. S. (eds.) Handbook of small animal practice. Saunders, Philadelphia, USA.

Holmstrom, S. E. 1995. Canine oral diagnosis. In: Crosley, D. A. \& Penmann, S. (eds.) Manual of small animal dentistry. Gloucestershire: British small animal veterinary association.

Leib, M. S. \& Monroe, W. E. 1997. Diseases of the oral cavity, pharynx, and salivary glands. In: Leib, M. S. \& Monroe, W. E. (eds.) Pratical small animal internal medicine. W. B. Saunders, Philadelphia.

Liptak, J. M. \& Withrow, S. J. 2007. Cancer of the gastrointestinal tract. In: Withrow, S. J. \& Wail, D. M. (eds.) Small animal clinical oncology. Saunders Elsevier, St Louis, USA.

López Arranz, J. S. 1991. Princípios de acto cirúrgico. In: López Arranz, J. S. \& Garcia Deila, A. (eds.) Cirurgia oral. Madrid: Interamericana McGrow Hill, Madrid.

Lucena, P. J., Ginel, J., Pérez, R., López, R., Chacón, F. \& Mozos, E. 1996. Tumores de cavidade oral em el perro: estúdio retrospectivo. Clínica Veterinária de Pequenos Animales, 16, 71-76.

Marreta, S. M. 1998. Maxillofacial surgery. The 
Veterinary Clinics of North America. Small Animal Practice, 28, 1285-1296.

Mayer, M. N. \& Anthony, J. M. 2007. Radiation therapy for oral tumors: canine acanthomatous ameloblastoma. The Canadian Veterinary Journal, 48, 99-101.

Meuten, D. J. 2016. Tumors in domestic animals. John Wiley \& Sons.

Morris, J. \& Dobson, J. 2001. Cabeza y cuello. Intermédica, 4, 101-102.

Natalini, C. C. 2007. Teoria e técnicas em anestesiologia veterinária. Srtmed, Porto Alegre, Rio Grande do Sul, Brasil.

Nelson, R. W. \& Couto, C. G. 2015. Medicina interna de pequenos animais. Elsevier Editora, Amsterdan.

Oakes, M. G., Lewis, D. D., Hedlund, C. S. \& Hosgood, G. 1993. Canine oral neoplasia. The Compendium on Continuing Education for the Practicing Veterinarian, 15, 17-31.

Pavlica, Z.; Erjavec, V.; Pecar, J. Ressection of a fibrossarcoma by bilateral maxillectomy in a seven years old mogrel dog. In: Proceedings of the 10th EDVS Congress, Berlin, 2001.

Polton, G. 2011. Canine oral tumours: common problems, simple solutions. Veterinary Ireland Journal, 64, 216-220.

Rodrígues-Quirós, J., Trobo Muñiz, J. \& San Román, F. 1998. Neoplasias orales en pequeños animales. Cirurgía maxilofacial I. Atlas de Odontología en Pequeños Animales. Grass Edicions, Madrid, Espanha, 1, 143-161.

Rosenthal, R. C. 2004. Segredos em oncologia veterinária. Artmed, Porto Alegre.

Roza, M. R. 2004. Odontologia em pequenos animais, Rio de Janeiro.

San Román, F. 1999. Atlas de odontologia de pequenos animais. São Paulo, 1, 217-241.

Soderstrom, M. J. \& Gilson, S. D. 1995. Principles of surgical oncology. Veterinary Clinics: Small Animal Practice, 25, 97-110.

Sorenmo, K., Kristiansen, V., Cofone, M., Shofer, F., Breen, A. M., Langeland, M., Mongil, C., Grondahl, A., Teige, J. \& Goldschmidt, M. 2009. Canine mammary gland tumours; a histological continuum from benign to malignant; clinical and histopathological evidence. Veterinary and Comparative Oncology, 7, 162-172.

Stebbins, K. E., Morse, C. C. \& Goldschmidt, M. H. 1989. Feline pral neoplasia: a ten-year survey. Veterinary Pathology, 26, 121-128.

Tholen, M. \& Hyot, R. F. 1989. Oral pathology. In: Bojrab, M. J. \& Tholen, M. (eds.) Small animal oral medicine and surgery. Lea \& Febiger, Philadelphia: Lea \& Febiger, p. 25-40, 1989.

Valentine, B. A. \& Eckhaus, M. A. 1986. Peripheral giant cell granuloma (giant cell epulis) in two dogs. Veterinary Pathology, 23, 340-341.

Velásquez, O. V., Farjado, M. R., Zamora, E. J. L. \& Martinez, C. J. S. 2005. Tumor frequency inhomeless dogs small sample population captured by public urban disease control center toluca city. Proceedings of the world small veterinary association congress. Mexico.

Verstraete, F. J. M. 2005. Mandibulectomy and maxillectomy. Veterinary Clinics of North America: Small Animal Practice, 35, 10091039.

Verstraete, F. J. M., Ligthelm, A. J. \& Weber, A. 1992. The histological nature of epulides in dogs. Journal of Comparative Pathology, 106, 169-182.

White, R. A. S. M. c. t. I. D., J.M.; Lacelles, D. D. $\mathrm{X}$. BSAVA:Manual of canine an feline oncology. Gloucester: BSAVA, p.161-167, 2003. 2003. Mast cell tumors. In: Dobson, J. M. \& Lacelles, D. D. X. (eds.) Manual of canine an feline oncology. Gloucester: BSAVA.

Wiggs, R. B. \& Lobprise, H. B. 1997. Veterinary Dentistry: principles and practice. LippincottRaven Publishers.

Withrow, S. J., Page, R. \& Vail, D. M. 2014. Withrow and MacEwen's small animal clinical oncology. Elsevier Health Sciences, St. Louis.

Woodward, T. M. 2002. Recurrent ossifying epulis in a dog. Journal of Veterinary Dentistry, 19, 82-85.

Yoshida, K., Yanai, T., Iwasaki, T., Sakai, H., Ohta, J., Kati, S., Ishikawa, K., Lackner, A. A. \& Masegi, T. 1999. Proliferative potential of canine oral epulides and malignant neoplasms assessed by bromodeoxyuridine labeling. Veterinary Pathology, 36, 35-41.

Article History:

Received 6 November 2017

Accepted 4 December 2017

Available online 10 February 2018

License information: This is an open-access article distributed under the terms of the Creative Commons Attribution License 4.0, which permits unrestricted use, distribution, and reproduction in any medium, provided the original work is properly cited. 